\title{
Chemical Examination of Sandbox (Hura Crepitans) Seed: Amino Acid and Seed Protein Solubility
}

\author{
G.O. Oyeleke ${ }^{1}$, O. Afolabi ${ }^{1}$, A. Ojo ${ }^{2}$ And R.O. Adetoro ${ }^{3}$ \\ ${ }^{1}$ Science Laboratory Technology Department, Osun State Polytechnic, Iree, Nigeria. \\ ${ }^{2}$ Food Science And Technology Department, Osun State Polytechnic, Iree, Nigeria. \\ ${ }^{3}$ Chemistry Department, Osun State College Of Education, Ila-Orangun, Nigeria.
}

\begin{abstract}
Amino acid composition as well as the seed protein solubility of (Hura crepitans) seeds was studied. The chemical scores for the determined amino acids of the seed in \% showed tryptophan, leucine, methionine and isoleucine with 175.71, 175.00, 161.82 and 134.52 as the most abundant amino acids in that order while lysine and phenylalanine with 44.29 and 45.71 respectively were the most limiting amino acids. The ratio of percentage essential and non-essential amino acids in the seed was found to be 79: 21. All the values determined for amino acids were higher than the FAO/WHO standard except for lysine, cysteine and phenylalanine where lower values were obtained. Four solvents (0.1M each of $\mathrm{NaOH}, \mathrm{Na}_{2} \mathrm{CO}_{3}, \mathrm{NaHCO}_{3}$ and $\mathrm{NaCl}$ ) were used to test for solubility of the seed protein and out of these, $0.1 \mathrm{M} \mathrm{NaOH}$ was found to be the most effective solvent compared to the deionized distilled water. The protein was found to be more soluble in the alkaline than the acidic medium with $P^{H} 4$ having the lowest protein solubility of $20 \%$ while $P^{H} 8$ have the highest solubility of 65\% after which increasing $\mathrm{pH}$ do not increase solubility and a relative stability established. The outcome of this work is a useful indication of how well protein isolate would perform when they are applied to food and to the extent of protein denaturation due to chemical treatment,
\end{abstract}

Keywords: Amino acid, chemical score, solubility, protein, essential, non-essential, limiting.

\section{Introduction}

Seed serves several functions for the plant that produced them on one hand such as nourishment of embryo, dispersed to a new location and dormancy during unfavourable conditions and on the other hand for human being in general for provision of energy and protein. Many seeds are edible and provide most edible oils and spices. They are also used in production of beverages and as thickening agents in recipes of several food items. Sandbox (Hura crepitans) seed of Euphobiaceae family is a native to tropical regions of North and South America. It is also common to Africa continent especially Nigeria where it is abundant. Earlier findings of some researchers on common seeds have been reported $[1,2,3]$. The first part of this research work pointed out that sandbox (Hura crepitans) contained $25.75 \%$ crude protein, $23.52 \%$ crude fat and $31.51 \%$ carbohydrate. With the above high protein value, the present work aimed at investigating further the amino acid profile as well as seed protein solubility of sandbox for industrial usage especially in food industries where chemical nature of the food during and after treatment is of paramount importance.

\subsection{Materials}

\section{Materials and Methods}

\subsection{Sampling and Sample Treatment}

Sandbox (Hura crepitans) seeds collected within the campus of Osun State Polytechnic, Iree, Nigeria and identified at botany department (herbarium unit) of Obafemi Awolowo University, Ile-Ife, Nigeria were used for this analysis. The seeds were sun dried, grinded, passed through a $2 \mathrm{~mm}$ sieve and stored in a polythene bag prior to analysis. The sample was defatted using $n$-hexane in a soxhlet extractor.

\subsection{Methods}

Amino acid composition of the seed was determined following AOAC methods [4] while the seed protein solubility by various extractants and at various $\mathrm{pH}$ was carried out by the method of Sathe [5]. Protein content in the sample was determined using the method of Gonzalez-Perez et al., [6]. 


\section{Results and Discussion}

\subsection{Results}

Table 1: Amino acid Profile and the Chemical Score of Hura crepitans Seed (\%).

\begin{tabular}{lccc}
\hline Amino acid & Value \pm S.D & FAO Ref. & $\%$ Chemical score \\
\hline Isoleucine & $5.65 \pm 0.01$ & 4.20 & 134.52 \\
Histidine & $2.86 \pm 0.10$ & - & - \\
Leucine & $7.85 \pm 0.02$ & 4.20 & 175.00 \\
Lysine & $1.86 \pm 0.03$ & 4.20 & 44.29 \\
Methionine & $3.56 \pm 0.04$ & 2.20 & 161.82 \\
Cysteine & $1.84 \pm 0.05$ & 2.00 & 92.00 \\
Cysteine + Methionine & $5.40 \pm 0.01$ & 3.50 & 154.29 \\
Phenylalanine & $1.28 \pm 0.03$ & 2.80 & 45.71 \\
Tryptophan & $2.46 \pm 0.04$ & 1.40 & 175.71 \\
Alanine & $6.25 \pm 0.11$ & - & - \\
Essential AA $(\%)$ & 79 & & \\
Non-essential AA $(\%)$ & 21 & & \\
\hline
\end{tabular}

Results are average of duplicate determination

AA- Amino acid

FAO [7]

Table 2: Hura crepitans Seed Protein Solubility in Selected Solvents (\%)

\begin{tabular}{lr}
\hline Solvent & Solubility \\
\hline Deionized distilled water & $10.6 \pm 0.2$ \\
$0.1 \mathrm{M} \mathrm{NaOH}$ & $36.5 \pm 0.2$ \\
$0.1 \mathrm{M} \mathrm{Na}_{2} \mathrm{CO}_{3}$ & $30.2 \pm 0.2$ \\
$0.1 \mathrm{M} \mathrm{NaHCO}_{3}$ & $18.5 \pm 0.1$ \\
$0.1 \mathrm{M} \mathrm{NaCl}$ & $26.5 \pm 0.5$ \\
\hline
\end{tabular}

Results are average of duplicate determination + S.D

Table 3: $\mathbf{P}^{\mathrm{H}}$ and Seed Protein Solubility (\%).

$\underline{\mathrm{P}^{\mathrm{H}}} \quad \%$ Seed protein solubility

$\begin{array}{ll}1 & 50 \\ 2 & 36 \\ 3 & 38 \\ 4 & 20 \\ 5 & 20 \\ 6 & 22 \\ 7 & 30 \\ 8 & 45 \\ 9 & 65 \\ 10 & 64 \\ & \end{array}$

\section{Discussion}

Table 1showed the amino acid composition of Hura crepitans seed. A total of ten amino acids were analyzed; isoleucine, histidine, leucine, lysine, methionine, cysteine, tryptophan, phenylalanine and alanine. The total essential amino acid was found to be $79 \%$ while the total non-essential amino acid was $21 \%$. Leucine with $(7.35 \pm 0.02 \%)$ was found to have the highest value followed by alanine $(6.25 \pm 0.11 \%)$ and isoleucine $(5.65 \pm 0.01 \%)$ respectively while phenylalanine was found to have the least value of $(1.28 \pm 0.03 \%)$. The value obtained for alanine was higher than (3.25\%) and (3.5\%) reported for dark and white cultivars of Sesamium indicum seeds [8]. The methionine + cysteine content of $(5.4 \%)$ was found to be higher than (3.5\%) reported by FAO [7]. The isoleucine and histidine contents were found to be $(5.65 \pm 0.01 \%)$ and $(2.86 \pm 0.10 \%)$ which were higher than $(3.16 \%$ and $0.98 \%)$ obtained for Lophira lanceolata seed by Lohlum, et al., [9]. The lysine 
$(1.86 \pm 0.03 \%)$ and phenylalanine $(1.28 \pm 0.03 \%)$ were found to be lower compared to $(3.71 \pm 0.01) \mathrm{g} / 100 \mathrm{~g}$ protein and $(5.29 \pm 0.06) \mathrm{g} / 100 \mathrm{~g}$ protein by Mohammed [10] for pumpkin seed. The presence of lysine makes it useful as enrichment to most cereals that lacks lysine. The tryptophan value of $(2.46 \pm 0.04 \%)$ was higher than $1.10 \pm 0.04$ $\mathrm{g} / 100 \mathrm{~g}$ protein reported by Mohammed [10] for pumpkin seed. From the chemical score of the various amino acids; tryptophan, leucine and methionine were most abundant amino acids while lysine and phenylalanine were the limiting amino acid. With these results, Hura crepitans seed could serve as a good source of tryptophan, leucine and methionine.

Table 2 showed the protein solubility in different solvents. The solubility profile of Hura crepitans is comparable to the findings of Abu-Tarboush et al., [11] on plant protein. The protein solubility obtained with the various solvents are higher compared to the seed protein solubility in deionized distilled water, with that of $0.1 \mathrm{M} \mathrm{NaOH}$ being the highest $(36.5 \pm 0.1 \mathrm{mg} / 100 \mathrm{~g})$ and $0.1 \mathrm{M} \mathrm{NaHCO}_{3}$ being the least $(18.5 \pm 0.1 \mathrm{mg} / 100 \mathrm{~g})$.

Table 3 showed the solubility profile of Hura crepitans seed protein at different $\mathrm{P}^{\mathrm{H}}$ values. The seeds exhibited the minimum protein solubility of $20-22 \%$ between $\mathrm{P}^{\mathrm{H}} 4-5$ and maximum protein solubility of $65 \%$ at $\mathrm{P}^{\mathrm{H}} 8$ and 10. Increasing the $\mathrm{P}^{\mathrm{H}}$ above $\mathrm{P}^{\mathrm{H}} 8$ did not increase the protein solubility. The above observation is similar to the finding of Magdi [12] on baobab seed.

Fig. 1 described the seed protein solubility against the $\mathrm{P}^{\mathrm{H}}$. The lowest solubility was found at $\mathrm{P}^{\mathrm{H}} 4$ and highest solubility at $\mathrm{P}^{\mathrm{H}} 8$ from where relatively stability was established. The protein was also found to be soluble at acidic and alkaline conditions.

\section{Conclusion}

The outcome of this work serves as a useful indication of how well protein isolate from the seed would perform when they are applied to food and also to the extent of protein solubility due to chemical treatment

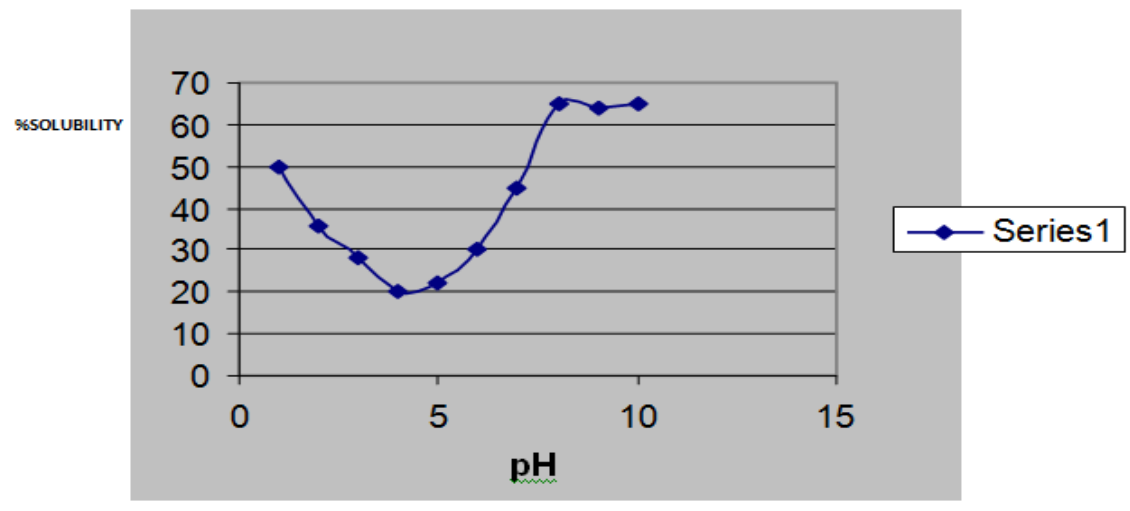

Fig.1: Seed Protein Solubility against $\mathrm{p}^{\mathrm{H}}$

\section{References}

[1] R.A. Oderinde, I.A. Ajayi, F.A. Dawodu and K.O. Adebowale, Chemical Composition of Pentaclethra macrophylla Seed and Seed Oil Grown in Nigeria. Riv. Ital. Sostanze Grasse. 74 (2003): 183-185.

[2] M.A. Fowomola and A.A. Akindahunsi, Nutritional Quality of Sandbox Tree (Hura crepitans Linn). J. Med. Food. Vol. 10(1) (2007):159-164.

[3] O.U. Njoku, I.C. Ononogbu, V.O. Nwaneri and J.O. Ugwanyi, Lipase Activities in Hura crepitans Seed Endosperm during Germination. Nig. J. Bot. a (1996): 21-26.

[4] AOAC, Official method of Analytical Chemist. $18^{\text {th }}$ Ed. (2005), Washington, D.C.

[5] S.K. Sathe, Solubilization and Electrophoretic Characterization of Cashewnut (Anarcadium Occidentale) Protein. Food Chem. 51 (1994):319-324.

[6] S. Gonzalex-Perez, J.M. Vereijken, G.A. Van Koningsveld, J.M. Gruppen and A.G.J. Voragen, Formation and Stability of Foams made with Sunflower (Helianthus annuus) Protein. J. Agric. Chem. 53 (2005):6469-6476.

[7] FAO, Protein Quality Evaluation. Standard Report of a joint FAO/WHO Expert Consultation. (1973), Food and Agriculture Organization of the U.N. Rome.

[8] A.H. Bahkali, M.A. Hussain and A.Y. Basahy, Protein and Oil Composition of Sesame Seeds (Sesamium indicum L.) Grown in the Gizan Area of Saudi Arabia. Int. J. Food Sci. \& Nutr.49 (1998):409-414.

[9] S.A. Lohlum, G.H. Maikidi and M. Solomon, Amino Acid Profile and Phytochemical Screening of L. lanceolata Seed. AFJAND. Vol.10 No1 (2010): 2012-2023.

[10] A.A. Mohammed, Chemical Composition and Oil Characteristic of Pumpkin (Cucurbita maxima) Seed Kernels. Res. Bult. No 129 (2004): 5-18.

[11] H.M. Abu-Tarboush, S.A.B. Ahmed and H.A. Al-Khatani, Some Nutritional and Functional Properties of Karkade (Hibiscus sabdariffa) Seed Product. Cereal chem. 7 (3) (1997): 352-355.

[12] A.O. Magdi, Chemical and Nutrient Analysis of Baobab (Adansonia digitata) Fruit and Seed Protein Solubility. Plant Food Hum. Nutr. 59 (2004):29-33. 